\title{
Evaluation of Fine Needle Aspiration Cytology in Diagnosis of Salivary Gland Lesions: A Teaching Hospital Based Study
}

\author{
Santanu Kumar', Wakil Ahmad² \\ ${ }^{1,2}$ Assistant Professor, Department of Pathology, Narayan Medical College and Hospital Jamuhar, Sasaram, Bihar.
}

\section{Abstract}

Background: FNAC is a cytodiagnostic method based on the morphological findings of individual cells, group of cells, and microparticles of tissue, acquired using a needle. The role of FNAC for the diagnosis of salivary gland masses is well documented. The traditional open biopsy is no longer justified because of the risk of tumor spillage and damage to the facial nerve. Subjects and Methods: FNAC procedure was explained to the patient and patient was placed in a comfortable position. They were then subjected to fine needle aspiration cytology. Aspirations were carried out with 21 or 22 gauge needles of varying lengths with $10 \mathrm{ml}$ syringes in a syringe holder after careful clinical examination of the lesion. Results: Chronic sialadenitis was the most common non-neoplastic lesion (13.2\%) followed by cystic lesions $(5.3 \%)$, acute on chronic sialadenitis $(3.9 \%)$ and chronic granulomatous inflammation (2.6\%). Pleomorphic adenoma (57.9\%) was the most common benign neoplasm. Warthin's tumour accounted for (6.6\%). Mucoepidermoid carcinoma was the most common malignant lesion $(5.3 \%)$ followed by acinic cell carcinoma (1.3\%), carcinoma-ex pleomorphic adenoma (1.3\%) and adenoid cystic carcinoma (2.6\%). Conclusion: Fine needle aspiration cytology of the salivary gland is a safe and reliable technique in the primary diagnosis of salivary gland lesions. Although, limitations are encountered while predicting specific lesions on cytology, especially when dealing with cystic and some malignant lesions.

Keywords: Fine needle aspiration Cytology and Salivary gland.

Corresponding Author: Dr. Wakil Ahmad, Assistant Professor, Department of Pathology, Narayan Medical College and Hospital Jamuhar, Sasaram, Bihar.

Email: bioymk@gmail.com

Received: February 2020

Accepted: February 2020

\section{Introduction}

The history of fine needle aspiration cytology (FNAC) goes back to the 1920s where it came into use simultaneously in Europe and the United states. ${ }^{[1,2]}$ FNAC is a cytodiagnostic method based on the morphological findings of individual cells, group of cells, and microparticles of tissue, acquired using a needle. The role of FNAC for the diagnosis of salivary gland masses is well documented. The traditional open biopsy is no longer justified because of the risk of tumor spillage and damage to the facial nerve. ${ }^{[3]}$ Themethod has a high degree of sensitivity in distinguishing the tumors from nonneoplastic lesions of salivary gland. ${ }^{[4,5]}$ Fine needle aspiration cytology (FNAC) is accurate, simple, rapid, inexpensive, well tolerated and harmless for the patient. ${ }^{[6]}$ Although salivary gland tumours are rare and they account for $2-6.5 \%$ of all the head and neck tumours, their superficial location, easy accessibility and high diagnostic accuracy makes FNAC a popular method for evaluating them. ${ }^{[7]}$ This technique assumes greater importance considering the lack of characteristic clinical or radiologic features that may suggest a particular diagnosis. Though, few symptoms and signs may suggest malignancy, most malignant salivary gland lesions cannot be differentiated from their benign counterparts on clinical criteria alone. ${ }^{[8]}$ Salivary gland swellings can result from tumours, an inflammatory process or cysts. The characteristic cytologic features of common salivary gland lesions have been welldelineated in literature. ${ }^{[9]}$ However, there also exist cytologic pitfalls and overlapping features that make an accurate diagnosis difficult in few cases. This has led to a wide-range of sensitivities (62-97.6\%) and specificities (94.3- 100\%) of cytologic diagnosis. ${ }^{[10,11]}$ Hence, the appropriate therapeutic management could be planned earlier, whether it was local excision for benign neoplasms, conservative management for non-neoplastic lesions, radical surgery for malignant tumours and chemotherapy or radiotherapy for metastasis and lymphoproliferative disorders. ${ }^{[12]}$ The aim of this study was to evaluate the spectrum of salivary gland lesions in our setting and to assess the diagnostic accuracy of FNAC for salivary gland lesions.

\section{Subjects and Methods}

This present study was conducted in the department of pathology, Narayan Medical College and Hospital, Sasaram, Jamuhar, Bihar, India., during the period from 
August, 2017 to July, 2019, which comprised of seventy six cases of salivary gland lesions, attending the outpatient and inpatient wards of surgery and ENT department of a tertiary care hospital were included in the study. The cases were thoroughly interrogated, clinically examined and relevant investigations done. FNAC procedure was explained to the patient and patient was placed in a comfortable position. They were then subjected to fine needle aspiration cytology. Aspirations were carried out with 21 or 22 gauge needles of varying lengths with $10 \mathrm{ml}$ syringes in a syringe holder after careful clinical examination of the lesion. The samples were placed on a glass slide and smears were made by inverting second glass slide over the drop and as it spreads, pulling the slides apart horizontally or vertically. Smears were stained by using MGG and Papanicolaou stain. Cytologic diagnosis was compared with histopathologic diagnosis wherever it was available.

\section{Results\& $D_{\text {iscussion }}$}

\begin{tabular}{|l|l|l|l|}
\hline Table 1: Age and Sex Distribution of Patients \\
\hline Age in Years & Male & Female & Total(\%) \\
\hline $21-25$ & 07 & 05 & $12(15.8)$ \\
\hline $25-30$ & 10 & 09 & $19(25.0)$ \\
\hline $30-35$ & 06 & 04 & $10(13.2)$ \\
\hline $35-40$ & 10 & 06 & $16(21.05)$ \\
\hline $40-45$ & 03 & 01 & $04(5.3)$ \\
\hline $45-50$ & 05 & 02 & $07(9.2)$ \\
\hline $50-60$ & 02 & 01 & $03(3.9)$ \\
\hline $60-65$ & 01 & 01 & $02(2.6)$ \\
\hline $65-70$ & 01 & 01 & $02(2.6)$ \\
\hline $70-75$ & 00 & 01 & $01(1.3)$ \\
\hline Total & 45 & 31 & $76(100)$ \\
\hline
\end{tabular}

Table 2: Distribution of salivary gland lesions

\begin{tabular}{|l|l|l|}
\hline Cytological Diagnosis & Cases (\%) \\
\hline Neoplastic & Benign & $49(64.7 \%)$ \\
& & \\
\cline { 2 - 3 } & Malignant & $08(10.5 \%)$ \\
\hline Non neoplastic & $19(25 \%)$ \\
\hline
\end{tabular}

Table 3: Frequency distribution of non-neoplastic and
Neoplastic lesions
\begin{tabular}{|l|l|l|}
\hline Cytological diagnosis & Cases (\%) \\
\hline $\begin{array}{l}\text { Non-neoplastic } \\
(19)\end{array}$ & Chronic sialadenitis & $10(13.2 \%)$ \\
\cline { 2 - 3 } & Cystic lesions & $4(5.3 \%)$ \\
\cline { 2 - 3 } & $\begin{array}{l}\text { Acute on chronic } \\
\text { sialadenitis }\end{array}$ & $3(3.9 \%)$ \\
\cline { 2 - 3 } & $\begin{array}{l}\text { Chronic granulomatous } \\
\text { inflammation }\end{array}$ & $2(2.6 \%)$ \\
\hline $\begin{array}{l}\text { Neoplastic } \\
\text { Benign(49) }\end{array}$ & Pleomorphic adenoma & $44(57.9 \%)$ \\
\hline Neoplastic & Warthin'stumour & $5(6.6 \%)$ \\
\hline \multirow{5}{*}{ Malignant(08) } & $\begin{array}{l}\text { Mucoepidermoid } \\
\text { carcinoma }\end{array}$ & $4(5.3 \%)$ \\
\cline { 2 - 3 } & Acinic cell carcinoma & $1(1.3 \%)$ \\
\cline { 2 - 3 } & Adenoid cystic carcinoma & $2(2.6 \%)$ \\
\cline { 2 - 3 } & $\begin{array}{l}\text { Carcinoma ex pleomorphic } \\
\text { adenoma }\end{array}$ & $1(1.3 \%)$ \\
\hline
\end{tabular}

There were 45 males and 31 females patients. The age range was 21 to 75 years with a mean age of 48 years. A total of 76 FNAC were done in the Department of Pathology, NaraynMedical College Hospital,Sasaram. [Table1] shows the Maximum number of cases was observed in age group 26-30 years. Commonest gland involved was parotid (71.05\%), followed by submandibular gland $(23.7 \%)$ and minor salivary glands $(3.9 \%)$ whereas no case of sublingual salivary gland lesion was observed in the present study. In the present study, non-neoplastic lesions accounted for $25 \%$, followed by $64.5 \%$ benign tumours and $10.5 \%$ malignant tumours[Table1].

Chronic sialadenitis was the most common non-neoplastic lesion $(13.2 \%)$ followed by cystic lesions $(5.3 \%)$, acute on chronic sialadenitis $(3.9 \%)$ and chronic granulomatous inflammation (2.6\%). Pleomorphic adenoma (57.9\%) was the most common benign neoplasm. Warthin'stumour accounted for (6.6\%). Mucoepidermoid carcinoma was the most common malignant lesion $(5.3 \%)$ followed by acinic cell carcinoma (1.3\%), carcinoma-ex pleomorphic adenoma $(1.3 \%)$ and adenoid cystic carcinoma (2.6\%) [Table3]. In the present study, benign neoplasms accounted for 49 cases $(64.5 \%)$. The rate of benign neoplasm was lower than other reports which ranged from 49 to $83 \% .^{[13-16]}$ We observed the pleomorphic adenoma as the commonest benign neoplasm similar to those previously reported number of studies. ${ }^{[13,17-}$ 19] Various authors have reported that the incidence of malignant tumours ranged from $15 \%$ to $32 \%$, and in the present study it accounted for $10.5 \%$ similar to Nguansangiam et al, which have found a lower rate of malignant neoplasms. ${ }^{[13,17,18]}$ In this study, the most common malignant salivary gland tumor was mucoepidermoid carcinoma which accounted for 5.3\% of all malignant neoplasms followed by acinic cell carcinoma and malignant mixed tumours. In contrast, Nguansangiam et al. have found that lymphoma is the commonest primary malignant salivary gland tumor followed by mucoepidermoid carcinoma. ${ }^{[13]}$ Parotid gland was observed as the commonest site of salivary gland lesions; $(72.3 \%)$ of all salivary gland lesions involved the parotid gland in this series. Almost similar distribution of salivary gland neoplasms in the parotid gland has also been described by Choudhury et al. ${ }^{[20]}$

A review of literature revealed a wide variation in the sensitivity and specificity of FNAC for salivary gland swelling in different populations and setups. ${ }^{[21-23]}$ The diagnostic sensitivity varied between $81 \%$ and $100 \%$, specificity was $94-100 \%$ and the accuracy of tumour typing was $61-80 \% .{ }^{[24]}$ Klijanienko et al found a sensitivity of $94 \%$, specificity of $97 \%$ and accuracy of $95 \% .{ }^{[25]}$ We found an overall diagnostic accuracy of FNAC to be $95.0 \%$. Pleomorphic adenoma is a biphasic neoplasm and no two pleomorphic adenomas look alike. Epithelial metaplasia, mainly squamous and oncocytic, and significant cytologicatypia may at times be worrisome. Aspiration of mucoidpaucicellular fluid or lack of stromal component may lead to a false positive diagnosis especially that of low grade mucoepidermoid carcinoma. Adenoid cystic carcinoma is a close differential of pleomorphic adenoma. This differentiation is very important as the surgical management is different. Adenoid cystic carcinoma shows basement membrane like material which may be misinterpreted as stromal component. Attention to nuclear 
morphology helps in distinguishing these two entities. One case initially diagnosed as Warthin'stumour was found to be low grade acinic cell carcinoma on histopathology. Interstitial infiltration of lymphoid cells is a prominent feature in some acinic cell carcinomas and cause confusion with Warthin'stumour. ${ }^{[26]}$

Diagnostic problems in FNA cytology of salivary glands are discussed by various authors, based on a very large series of cases. Their vast experience proves utility of FNAC in salivary glands beyond doubt. It is further stated that if established diagnostic criteria are present and are strictly observed, a high level of accuracy can be achieved. There remains however, a proportion of problematic cases depending on level of experience, continued desire to better oneself and acceptance of limitations. In such cases the uncertainty must be openly conveyed to the surgeon, rather than issuing a misleading report that will lead to inappropriate surgery.

\section{Conclusion}

These findings suggest that, fine needle aspiration cytology of the salivary gland is a safe and reliable technique in the primary diagnosis of salivary gland lesions. Although, limitations are encountered while predicting specific lesions on cytology, especially when dealing with cystic and some malignant lesions. Lastly every clinician who uses fine needle aspiration cytology must be aware of the limitations of the method.

\section{References}

1. Dudheonand LS, Patrick CV. A new method for the rapid microscopical diagnosis of tumors. Br J Surg 1927;15(8):250-261.

2. Martin HE, Ellis EB. Biopsy by needle puncture and aspiration, Annals Surg. 1930;92(2);169-181.

3. McGuirt WF, McCabe BF. Significance of node biopsy before definitive treatment of cervical metastatic carcinoma. Laryngoscope 1978;88(4);594-597.

4. Costas A, Castro P, Mart'in-Granizo R, Monje F, Marron C, Amigo A. Fine needle aspiration biopsy (FNAB) for lesions of the salivary glands. Br J Oral Maxillofacial Surg 2000; 38(5):539-542.

5. Stewart CJ, MacKenzie K, McGarry GW, Mowat A. Fine-needle aspiration cytology of salivary gland a review of 341 cases. Diag Cytopathology 2000;22(3):139- 146.

6. Fernandes GC, Pandit AA. Diagnosis of salivary gland tumours by FNAC. Bombay Hospital J 2000; 42:108-11.

7. Mavec P, Eneroth CM, Franzen S, Moberger G, Zajicek J. Aspiration biopsy of salivary gland tumours. Acta Otolaryngol 1964;58:471-84.

8. Daneshbod Y, Daneshbod K, Khademi B. Diagnostic difficulties in the interpretation of fine needle aspirate samples in salivary lesions: Diagnostic pitfalls revisited. Acta Cytol. 2009;53:53-70.

9. Kocjan G, Shah KA. Churchill Living stone. 3rd Edition. Edinburgh; 2010. Salivary glands. In :Gray W, Kocjan G, editors. Diagnostic Cytopathology. pp. 231-52.

10. Kocjan G, Nayagam M, Harris M. Fine needle aspiration cytology of salivary gland lesions: advantages and pitfalls. Cytopathology. 1990;1:269-75.

11. Orell SR. Diagnostic difficulties in the interpretation of fine needle aspirates of salivary gland lesions: the problem revisited. Cytopathology. 1995;6:285-300.

12. Cohen MB, Fisher PE, Holly EA, Ljung BM, Lowhagen T, Bottles K. Fine needle aspiration biopsy diagnosis of mucoepidermoid carcinoma.

13. Nguansangiam S, Jesdapatarakul S, Dhanarak N, Sosrisakorn K. Accuracy of fine needle aspiration cytology of salivary gland lesions: routine diagnostic experience in Bangkok, Thailand. Asian Pacific Journal of Cancer Prevention. 2012;13(4):1583-8.

14. Tan LG, Khoo ML. Accuracy of fine needle aspiration cytology and frozen section histopathology for lesions of the major salivary glands. Annals of the Academy of Medicine Singapore. 2006;35(4):242-8.

15. Mihashi H, Kawahara A, Kage M. Comparison of preoperative fineneedle aspiration cytology diagnosis and histopathological diagnosis of salivary gland tumors. Kurume Medical Journal. 2006;53(1-2):2327.

16. Jan IS, Chung P, Weng M. Analysis of fine-needle aspiration cytology of the salivary gland. Journal of the Formosan Medical Association. 2008;107(5):364-70.

17. Cajulis RS, Gokaslan ST, Yu GH, Frias-Hidvegi D. Fine needle aspiration biopsy of the salivary glands: a fiveyear experience with emphasis on diagnostic pitfalls. Acta Cytologica. 1997; 41(5):1412-20.

18. Boccato P, Altavilla G, Blandamura S. Fine needle aspiration biopsy of salivary gland lesions: a reappraisal of pitfalls and problems. Acta Cytologica. 1998;42(4):888-98.

19. Das DK, Petkar MA, Al-Mane NM, Sheikh ZA, Mallik MK, Anim JT. Role of fine needle aspiration cytology in the diagnosis of swellings in the salivary gland regions: a study of 712 cases. Medical Principles Practice. 2004;13(2):95-106.

20. Choudhury AA, Sultana T, Siddique BH, Amin ASA. Diagnosis of parotid gland mass by the fine needle aspiration cytology (FNAC) and its histopathological correlation-2 years study in BSMMU, Dhaka. Bangabandhu Sheikh Mujib Med Uni J. 2011;4(2):65-9.

21. Murai N, Taniguchi Z, Takahashi Y, Kuboshima F, Tateya I. A study of salivary gland aspiration cytology reporting: guideline validity. Nihon Jibiinkoka Gakkai Kaiho. 2011;114(7):615-9.

22. Piccioni LO, Fabiano B, Gemma M, Sarandria D, Bussi M. Fine needle aspiration cytology in the diagnosis of parotid lesions. Acta Otorhinolaryngol Ital. 2011;31(1):1-4.

23. Singh A, Haritwal A, Murali B. Correlation between cytology and histopathology of the salivary gland. Australas Med J. 2011;4(2):6671.

24. Young JA. Diagnostic problems in fine needle aspiration cytopathology of the salivary glands. J Clin Pathol. 1994;47:193-8.

25. Klijanienko J, Vielh P, Batsakis JD. Monographs in clinical cytology. Vol. 15. Salivary gland tumours. Basel, Switzerland: Karger. 2000.

26. Orell SR, Sterrett GF, Whitaker D. Fine Needle Aspiration Cytology. Acta Otorhinolaryngol Ital 2005;17(4):41-82.

Copyright: (C) the author(s), 2020. It is an open-access article distributed under the terms of the Creative Commons Attribution License (CC BY 4.0), which permits authors to retain ownership of the copyright for their content, and allow anyone to download, reuse, reprint, modify, distribute and/or copy the content as long as the original authors and source are cited.

How to cite this article: Kumar S, Ahmad W. Evaluation of Fine Needle Aspiration Cytology in Diagnosis of Salivary Gland Lesions: A Teaching Hospital Based Study. Asian J. Med. Res. 2020;9(1):PT06-PT08.

DOI: dx.doi.org/10.47009/ajmr.2020.9.1.PT2

Source of Support: Nil, Conflict of Interest: None declared. 